\title{
SULISMADI, WINARSIH, DEMOCRATIC LEADERSHIP SYSTEM TO PURSUIT THE \\ DEMOCRATIC LEADERSHIP SYSTEM TO PURSUIT THE VISION, MISSION, AND GOALS OF COMMUNITY DEVELOPMENT
}

\author{
Sulismadi $^{1}$ dan Siti Nurul Fitriyah Winarsih ${ }^{2}$ \\ ${ }^{1,2}$ Department of Sociology, Faculty of Social and Political Sciences, \\ University of Muhammadiyah Malang \\ Email: 1sulismadi@umm.ac.id, ${ }^{2}$ fitriawinarsih64@gmail.com
}

\begin{abstract}
The role of the rural village government in organizing their people to participate in the development program is the success measurement of community development. A democratic leader views his role as both coordinator and integrator, putting himself to control, manage, and supervise his region without precluding the people's right to express their ideas. This study aims at explaining the people's responses towards unsuccessful infrastructure development by their leader and the village's government. This study reviewed the phenomena using the qualitative approach; the data analysis used descriptive method to analyze the data. An active role of the society in the infrastructure development shows the concern on the local environment. The emergence of activity whose primary purpose is to initiate infrastructure development such as road and bridge can provide advantages for the local people and maintain a good relation among those people.
\end{abstract}

Keywords: Democratic, leadership, development

\section{INTRODUCTION}

Leadership system is one of the factors that affect regional management in achieving the mission, vision, and purpose of the development. Democratic leadership is the ability to change other people to be willing to cooperate to achieve mutual goals in various ways or activities, which will be a determined agreement by the leader and subordinates altogether. (Pananrangi, 2017: 37-38). Democratic leadership has a plus point in achieving the vision, mission, and goal of the community development; the advantage of this type of leadership lies where each task and authority are well-designed that resulting in the clarity of each division.

Mulyoagung rural village of Dau sub-district in Malang, East Java applies democratic leadership. At first, Muyoagung consisted of four hamlets, namely Dermo, Jetak Ngasri, Sengkaling, and Jetis. In 1975, there was an official split to divide Jetak Ngasri into two hamlets. The division was according to the compliance of its area width and population. Until now, both hamlets have two different names due to the split; they are Jetak Lor and Jetak Ngasri. The history of Mulyoagung's leader started during 
the Dutch colonization, with the first village head named Bapak Ngatemi from Jetis hamlet. He stayed to become the village chief until Japan colonized Indonesia. The first head of the village election was in 1987; it goes until the present time. Nevertheless, a democratic election of a village chief does not guarantee that the development in the village can achieve its vision, mission, and goal accordingly and appropriately.

Mulyoagung village is currently having issues in its infrastructure development. Nevertheless, a well-established facility is a key to economic growth using a financial allocation from both the public and private sectors. The infrastructure also holds a significant role in regional and national development. It also has a substantial impact on the development o life quality and human prosperity. (Haris, 2005: 1). An infrastructure issue that once occurred in Mulyoagung is the stalled of the Regional Development Budget in 2014; the case left a task for the current period to solve. The development stalling issue has a significant effect on infrastructure development in the village of Mulyoagung. A lousy drainage and road construction, are two examples of the impact of the budget stalling issue.

According to the issues above, this research aims at (1) explaining the community's responses towards the stalling infrastructure development; (2) finding out further follow-ups for the village's chief and the local government agency towards the stalling infrastructure development.

\section{RESEARCH METHODS}

This research applied a qualitative approach by using the qualitative descriptive method of data analysis. The instrument of qualitative research covers the researcher, data collection through the triangulation model, an inductive data analysis, and its result emphasizes more to its meaning instead of a generalization. (Sugiyono, 2011: 9). The research used the qualitative approach to explain the social phenomena of democratic leadership to achieve the vision, mission, and social development goals, mainly through the infrastructure construction in Mulyoagung village.

The appointment of informants in this research was by considering several facts on the field. Therefore, this research used the purposive sampling method based on the criteria by the researcher. This research also has the crucial informant, that is the chief of Landungsari, who is capable of providing information relating to the research problems. The subject of this research is the neighbourhood heads and a community leader of the surrounding area of the infrastructure construction.

The data source of this research consists of two, namely (1) primary data, which derives from a trusted source to support the study with data relevant to the research's title. This primary data comes from the local government agency and the people of Mulyoagung that become the object of the infrastructure construction, and (2) 
secondary data that derives from the official village documents and relevant information from the internet.

\section{THEORETICAL FRAMEWORK}

The structural functionalism theory was first developed and introduced by Talcott Parsons. Parson is a Contemporary Sociologist who applied a functional approach to view a particular society, both in terms of its function and process. His approach always conveys regularity in social life in America; he based his thoughts on the idea from Auguste Comte, Emile Durkheim, Vildredo Pareto, and Max Weber. (Hasfi dan Maulana, 2019: 180).

Parson's structural functionalism developed four functional imperatives for the action system, namely the AGIL scheme. AGIL is a group of activities that aims at fulfilling one or more of the system's demand. According to the mentioned definition, Parsons believes that there are four functional imperatives required for shaping the characteristics of the whole system.

To make a system survives, it must have four functions: (1) Adaptation: the system must overcome its external situational requirements. The system must adapt to the environment and, at the same time, try to make it complies with its specifications; (2) Goals: the system must define and achieve its primary goals, (3) Integration: the system must manage relation among divisions of its components. The system must be able to configure the ties among the three functional imperatives (A, G, and L), (4) Pattern Maintainance Latency: the system must complete, maintain, and renew the individual motivation and cultural patterns that create and keep them. (Ritzer dan Dounglas, 2014: 257).

Parsons designated his AGIL scheme applicable for all levels of his theoretical system. The behavioural organism is an action system that handles an adaptation function by adjusting and changing the external world. The behavioural system runs its goal achievement function by defining the system goals and mobilizing the resources for that purpose. The social network imposes the integration function by controlling parts that belong to its components.

Finally, the cultural system runs the latency function by equipping the actors with norms and values that motivate them to do a particular action. Parsons has a bold insight into the social analysis level and its relations. His hierarchical setting and integrated levels are precise. Parsons believes that the system consists of two aspects. The first aspect shows that every low level provides requirements and energy required by the higher level. On the other hand, the second aspect indicates that the higher level takes control over the lower levels based on the prevailing hierarchy.

There are seven assumptions derived from Parsons' finding on the structuralfunctionalism. He suggests that (1) the system has an order and interdependent parts, (2) 
System tends to become an equilibrium, or a set of rules that can maintain itself, (3) System can undergo a structural change and become static. Another Parsons' assumptions say that (4) A particular part of a system can affect the form of another component, (5) System maintains its border with the environment. (6) Allocation and integration are the two fundamental processes required to form an equilibrium system, and (7) System tends to maintain its relation with all parts as a whole, to control the environmental variation, and to control the tendency to change the system from the inside part.

\section{DISCUSSION}

This research discusses the attempts to reach the vision, mission, and development goals at Mulyoagung village. The research problems are issues in the democratic government system, infrastructure construction, and the local government agency's response in reaction to the existing issues.

\section{Vision and Mission of Mulyoagung Village}

The village's vision is to achieve a peaceful, prosperous, advance and righteousness situation for its people. Meanwhile, the village's missions are (1) to continue the existing programs which have started from the previous period of government cycle as stated officially, (2) to empower all social potentials, such as human and natural resources, (3) to establish an orderly, harmonious, and safe environment for the people.

\section{The Village's Chief Efforts for the Community Development}

The village applies the democratic election in electing the village's chief; the people have the freedom to give their direct ballot for the chief's candidate. Yet, in its practice, the village's head can serve for two periods according to the majority votes. The most occurring issue, in this case, is that the previous work period cannot complete the infrastructure construction as planned in their work plan. The local government budget has not completed yet due to the stalling projects of road, drainage, bridge, and pavement constructions. The programs have faced many issues considered as significant stalling problems for infrastructure development.

The head of the Mulyoagung village has attempted to overcome the issues by acting as the decision-maker once the problems emerge; his decision represents the people's will. The decision derives from the deliberation process among the local government functionaries based on the people's report. The following is an interview citation with one of the informants," If there is infrastructure construction issue as mentioned, the budget request can go directly to the local government agency. We can report the construction situation and things that need to continue the project. The report 
can be in the form of budgeting proposals. The last step is to propose for approval from related parties."

The village's chief, in the attempts to reach the vision, mission, and development goals, makes direct contact with the people and discuss the issue in-depth to achieve mutual consensus. The agreement will then become the way to accomplish development purposes. A successful leadership style means that it can solve all problems of Mulyogung village, and at the same time, it can create a peaceful and serene life for the people.

\section{Democratic Leadership Style of Mulyoagung Local Offical Government \\ a. Informant I (The Chief of Village Consultative Divison)}

There are two ways to elect the chief of the Village Consultative Division can be in two ways, direct and indirect. The legal base for this election is Regulation Number 6, the Year 2015 regarding political life in the village. The direct election is similar to the nation's general election, while the indirect election is by taking the votes from village representatives through the neighborhood heads who will attend the village deliberation to appoint all forces.

The problem that occurred when serving the BPD chief is the inability to forming an independent team; this is due to all representatives belongs to the community's choice, who have different characteristics and criteria. Other additional causes of this issue are the inexistence of competence test before becoming a leader and also the absence of passing grade for the team member criteria. There are simple criteria agreed by the community, which is the minimum age and educational background. The standard says that the minimum age is twenty-five and must have graduated from senior high school; nevertheless, these criteria do not ensure the presence of other capacities required for becoming the members of this division. The following is an interview citation with the BPD chief," Sometimes the existing team does not have enough capacity to discuss the economy. On different occasions, due to their limited knowledge, they also cannot follow the discussion about law and legal issues."

Apart from the human resource issue, the village also faces a financial problem due to the late commencement of fund disbursement. There is a fixed rule based on the ministry regulation, saying that there are three stages of fund disbursement in one year, which covers $40 \%, 40 \%$, and $20 \%$ for each term; unfortunately, the delay takes a longer time than the estimation. Unfortunately, the fund also contains the wage of village government officers. In response to that fact, Moesanto (the BPD chief) commented," Rome was not built in one night, it takes hundreds of years to build a nation, and it requires consistency. Yet, our country only has five years of leadership."

According to Moesanto, the development execution plan takes five years to be ready, 
and the expansion also requires another five years; therefore, leadership cannot prevail based on the number of years. There must be a correction state from the people that shall be any deviation or failure during the administration of a particular leader. A different condition if the leader has been acting according to the comprehensive work plan, yet it does not create any advancement; this would mean that the people bear the consequences and disadvantages. The worse case is that the election result has a leader who is incapable of administering the region. The fact that a particular person can become the chief for three periods instead of two periods support the previous statement on the phenomena of the ruling incapable village head.

The target to achieve is to run the function and duty of BPD professionally and to the maximum extent; therefore, the BPD will be able to formulate a qualified regional government budget (APBD). A leader becomes successful if his region is safe and prosperous.

\section{b. Informant III (Kepetengan)}

Kepetengan must ensure the safety and harmony of the society; this function sits under the village secretary of Mulyoagung local government. Therefore, this function is a technical officer in terms of safety and orderliness. Kepetengan works based on the decree of the village chief. The initial stage includes a preliminary fit and proper test to find out the candidate's skill and ability.
Besides that, the village chief also considers the candidate's previous work experiences and expertise.

The following is the interview result with the Kepetengan officer," Before serving as the Kepetengan. I was already active as the secretary of BPD. Therefore, I fully understand the society in Mulyoagung village, which consists of five hamlets; they are Dermo, Jetak Lor, Jetak Ngasri, Jetis, and Sengkaling. We take care of the safety and orderliness of these five hamlets. The most common occurring situation in the society is motor vehicle theft and also the infrastructure issues such as the unrealized bridges and asphalt paving process."

\section{c. Informant III (Kuwowo)}

Kuwowo acts in the village development sector, such as proposing to the government to build the road, building, bridge, and other facilities as the village's infrastructure. The following is the interview result with the Kuwowo," The development and facility constructions are the responsibility of Kuwowo. For example, the agricultural sector in Mulyoagung that includes irrigation, is under the Kuwowo authority, including the documentation process. For example, there is a ministry program delivered to the village chief; the Kuwowo will achieve direct instruction to share the information to the society. Nevertheless, the program commencement will take both Kuwowo, village chief, and other related local government officers to proceed even though everyone has different functions. 


\section{d. Informant IV (the village chief of Dermo hamlet)}

His vision and mission are to continue the development to benefit society and, at the same time, try to achieve a better environment and life stage in terms of safety and prosperity in Dermo. The work program is mainly to maintain and develop agricultural and farming products by the local people, especially the Dermo hamlet. There is voluntary work that takes place every week to keep the cleanliness in the Dermo hamlet of Mulyoagung village. The purpose of having the plan is to prevent floods, which often occurs during the rainy season.

During his service as the hamlet chief, he promotes living in harmony for all the people by practicing deliberation in solving every emerging issue in society. The target that the hamlet chief wants to achieve is to promote tax payment completion by at least $80 \%$. The chief's value that put forward democracy in the form of mutual consensus is his strongest point as a kamituwo.

The most occurring issues are the land problems and damaged public road that needs fixing and reconstruction due to the high level of rainfall that causes annual floods. The following is the interview citation with the hamlet chief of Dermo," The people usually solve the infrastructure issues by themselves because the village often does not respond well towards the fund request. Therefore, the hamlet people look for their solution to the problems. Some of the issues are the lack of land certificates, conflicts in art, and cultural sectors due to the unawareness conscience between the respected fields.

The kamituwo is in charge to act as a mediator and the elders whenever there is any dispute and conflict occurs in the society; he would suggest the deliberation step and lead the process until they reach a mutual agreement. The kamituwo also acts as the supervisor whenever there is any social activity; he facilitates and provides supportive suggestions for the success of the events. The leadership of a kamituwo is triumphant upon the achievement of harmonious life in his region, with safe and prosperous people.

\section{e. Informant $v$ (The chief of Neighborhood 1/Community Association 1)}

The vision and mission are to achieve continuous and sustainable development, especially the infrastructures in the respected neighborhood. The chief's work program is to make the administrative process more comfortable to access by society. The head has been serving since the year 2010 through direct election of the people based on the approved criteria, such as the sense of responsibility and putting forward the public interest of the Dermo hamlet. The goal during his service period is to create a harmonious and safe environment for the people.

During his service, the chief targets to establish awareness among people to respect each other and to maintain the safety and harmonious living in the area. He 


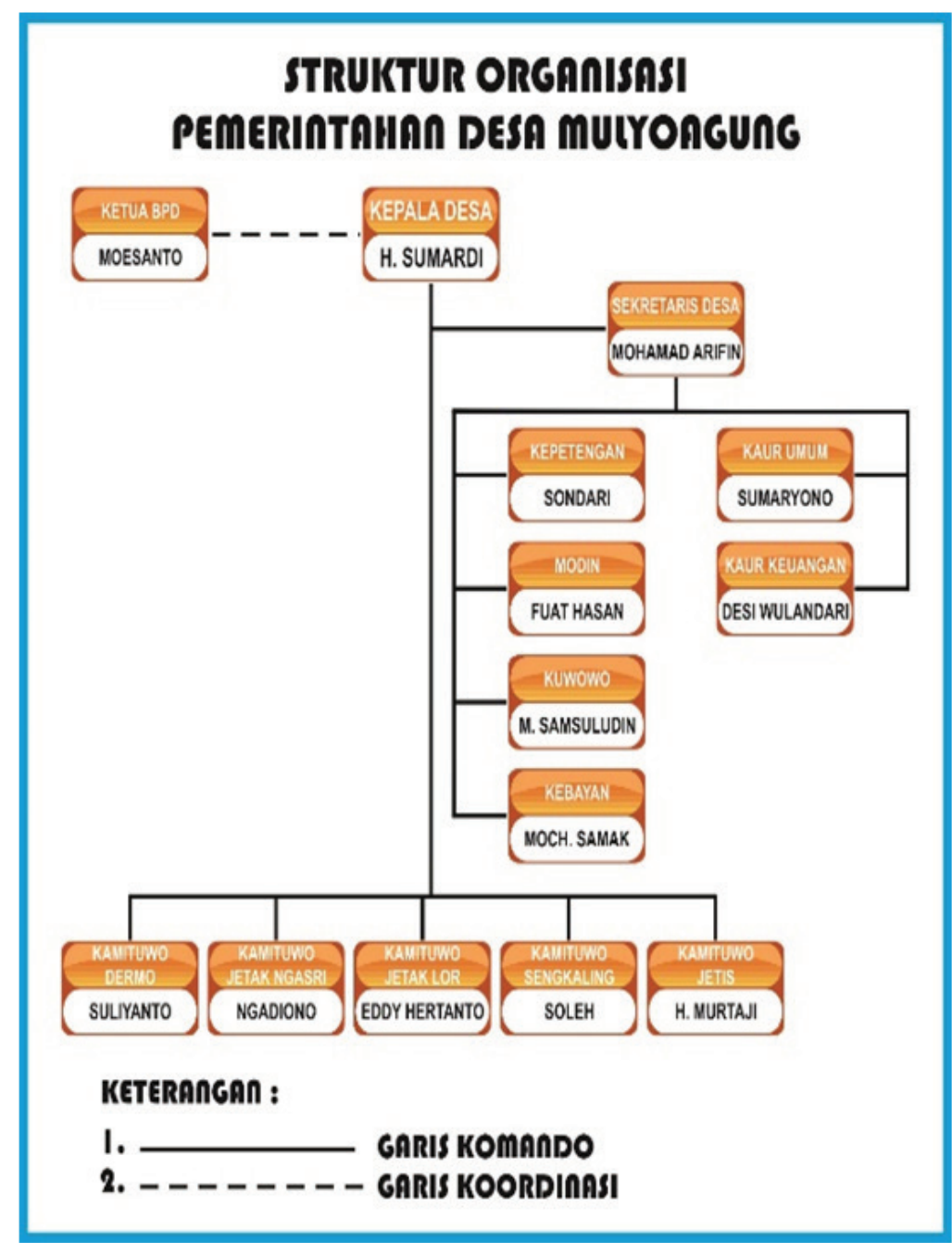

Organization Structure of Mulyoagung Village

tried to act wisely to be able to reach all age levels. In overcoming various personal and infrastructural issues, he makes appropriate approaches to have a decent discussion in reaching an agreement. His leadership is successful if he can create peacefulness and harmony for all the people in his region.

\section{CONCLUSION}

Based on the discussion and explanation concerning the democratic leadership style to achieve the vision, mission, and development goals for the society, especially Mulyoagung village, the local government has a significant role in supporting and encouraging the people to take an active part in the existing infrastructural developments.

The society's participation in infrastructural development proves their awareness towards the environment. The project aims at constructing and repairing the public infrastructures such as roads, bridges, and others with an expectation that it will provide benefits for the people and create harmony among people. The issues settlement through mutual deliberation that 
includes all society members is significant to prove that Mulyoagung village has applied and practiced a sound democratic leadership system.

\section{SUGGESTION}

According to the conclusion, the researcher suggests Mulyoagung village maintain and increase the participation of its people in the development programs, especially in the infrastructural ones, which has been better in practice and providing a more comfortable facility for all people. The initiative must remain until the end of the service period to increase public prosperity and welfare.

The researcher also expects the people to remain active in all infrastructural development as the main actor to achieve success in the programs.

\section{BIBLIOGRAPHY}

Akbar, Husaini Usman dan Purnomo Setiadi. 2011. Metodologi Penelitian Sosial, Jakarta: Bumi Aksara.

Azhari, Aidul f. 2005. Menemukan Demokrasi. Surakarta: Muhammadiyah University Press.

Bruhn, John G. and Howard M. Rebach. 2007. Sociological Practice Intervention and Social Change, Springer Science + Business Media.

Dwi Narwoko \& Bagong Suyatno. 2004. Sosiologi Text Pengantar \& Terapan. Jakarta: Prenadamedia Group.
Keating, charles J. 1986. Kepemimpinan, Teori, dan Pengembangannya. Yogyakarta: Kanisius.

Koentjaraningrat. 1967. Beberapa Pokok Antropologi Sosial, cet.1, Jakarta: Dian Rakyat.

Pananrangi, Andi Rasyid. 2017. Etika Birokrat. Makassar: CV Sah Media. ISBN 978-602-6928-18-4

Ritzer, George. 2012. Teori Sosiologi "Dari Sosiologi Klasik Sampai Perkembangan Terakir Postmodern". Yogyakarta: Pustaka Pelajar.

Ritzer, George dan Douglas J. Goodman. 2014. Teori Sosiologi "Dari Teori Sosiologi Klasik Sampai Perkembangan Mutakhir Teori Sosial Postmodern". Yogyakarta: Kreasi Wacana.

Sattar. 2017. Pengantar Bisnis. Yogyakarta: Grup Penerbitan CV Budi Utama.

Sorensen, Georg. 1993. Democracy and Democration: Process and Prospects in a Changing World. Aarhus: Westview Press.

Sugiono. 2012. Metode Penelitian Kuantitatif Kualitatif dan R\&D. Bandung: Alfaberta Cv.

Sumidjo, Waluyo. 1986. "Buku Materi Pokok Kepemimpinan", Jakarta: Karunika Universitas Terbuka.

Thoha, Miftah. 1995. Kepemimpinan dalam Manajemen, Jakarta: PT Raja Grafindo Persada.

Zulkarimen, Nasution. 2007. Komunikasi Pembangunan (Pengenalan Teori dan 
Penerapannya). Jakarta: PT Raja Grafindo Persada.

Manik, Jeanne Darc N. 2016. Kekuasaan dan Kepemimpinan Sebagai Proses Sosial dalam Bermasyarakat. Diakses pada 16 Januari 2020 melalui media. neliti.com.

Maulana, Nur Malik dan Nurul Hasfi. 2019. Implementasi Teori Fungsional Struktural dalam Regulasi Penyiaran Digital di Indonesia. Jurnal Sosioteknologi Institut Teknologi Bandung, Vol 18, No.2.

Nopitasari, Elsa dan Herry Krisnandy. 2018. Pengaruh Gaya Kepemimpinan Demokratis, Motivasi Intrinsik Dan Disiplin Kerja Terhadap Kinerja PT Pangansari Utama Food Industry. Jurnal OIKONOMIA, Ilmu Manajemen, Fakultas Ekonomi, Universitas Nasional Jakarta. Vol. 14 No. 1, ISSN: 1693-143X

Rossian, Widyanilam dan Riris Loisa. 2019. Analisis Gaya Komunikasi Kepemimpinan Kharismatik. Jurnal Fakultas Ilmu Komunikasi Universitas Tarumanagara, Vol. 3, No. 1, Juli 2019, EISSN 2598-0785.
Sulastri, Nindi dan Bachruddin Saleh. 2019. Pengaruh Gaya Kepemimpinan Demokratis Terhadap Kinerja Karyawan Perusahaan BPJS Ketenagakerjaan Cabang Soekarno Hatta Bandung. Bandung: Jurnal Prodi S1 Administrasi Bisnis Fakultas Komunikasi dan Bisnis Universitas Telkom, Vol.6, No.1.

Wicaksono, Ferri. 2018. Kiai Kharismatik dan Hegemoninya (Telaah Fenomena Habib Syech bin Abdul Qadir Assegaf). Yogyakarta: Jurnal Pemerintahan dan Politik, Universitas AMIKOM Yogyakarta, Vol 3, No. 3, E-ISSN 25022032.

Haris, Abdul. 2005. Pengaruh Penggunaan Tanah Terhadap Keberhasilan Pembangunan Infrastruktur dan Ekonomi. Direktorat Tata Ruang dan Pertahanan, Bappenas. Diakses pada 4 Maret 2020 melalui https:// bappenas.go.id/files/3013/5228/3483/05a bdul_20091014131228_2260_0.pdf.

Zakky. 2019. Pengertian Sistem Menurut Para Ahli dan Secara Umum. Diakses pada 16 Januari 2020 melalui https://www. zonareferensi.com/. 